Volume 10 Issue 4

\title{
○o \\ Extended DNA analyses: surveillance technology at the intersection of racism and sexism
}

\author{
$\square$ Isabelle Bartram University of Freiburg \\ OPEN Tino Plümecke University of Freiburg \\ Andrea zur Nieden University of Freiburg \\ DOI: https://doi.org/10.14763/2021.4.1603
}

Published: 7 December 2021

Funding: This article was supported by a grant from the German Federal Ministry of Education and Research (BMBF), funding number 01GP1790.

Competing Interests: The author has declared that no competing interests exist that have influenced the text.

Licence: This is an open-access article distributed under the terms of the Creative Commons Attribution 3.0 License (Germany) which permits unrestricted use, distribution, and reproduction in any medium, provided the original work is properly cited. https://creativecommons.org/licenses/by/3.0/de/deed.en

Copyright remains with the author(s).

Citation: Bartram, I. \& Plümecke, T. \& zur Nieden, A. (2021). Extended DNA analyses: surveillance technology at the intersection of racism and sexism. Internet Policy Review, 10(4). https://doi.org/10.14763/2021.4.1603

Keywords: Surveillance, Genetic data, DNA

\begin{abstract}
Genetic data contains a multitude of highly personal information and is therefore deemed an especially sensitive data category by data protection laws. But technological advances and the increasing demands of security policymakers have led to the continuous expansion of governmental authority over DNA extraction, analysis and storage. The protection of women from sexual crimes is often put forward as grounds to legitimise these expansions. Sexism and racism intersect in the most recent debate on further policy change, building on existing public fears of the threat posed by unknown male migrants to white German women and presenting controversial DNA technology as a solution.
\end{abstract}


This paper is part of Feminist data protection, a special issue of Internet Policy Review guest-edited by Jens T. Theilen, Andreas Baur, Felix Bieker, Regina Ammicht Quinn, Marit Hansen, and Gloria González Fuster.

\section{Introduction}

Genetic data contains a variety of highly personal information, such as genealogical relationships, health and other characteristics. DNA, the carrier of our genetic information, is present in almost every cell of our bodies and is highly personal-even intimate-because it is fundamentally individual and unchangeable. When we move through the world, it is almost unavoidable to leave DNA traces everywhere, yet its analysis via complex technology is usually neither accessible nor comprehensible to the owner of the DNA. Therefore, DNA is deemed a particularly sensitive data category by European and German data protection laws (Weichert, 2018). The European GDPR ${ }^{1}$ defines genetic data as "personal data relating to the inherited or acquired genetic characteristics of a natural person which result from the analysis of a biological sample from the natural person in question" and lists it as "special categories of personal data" (art. 9). A person has to consent fully to use of this data by a third party, e.g. for research purposes. Furthermore, in Germany genetic data is also protected by the Gendiagnostikgesetz ${ }^{2}$ (German Genetic Diagnostics Act) that aims to prevent discrimination based on genetic data.

The very sensitive properties of DNA have generated interest from police authorities who wish to access the data and utilise it in their investigations. During the last decades, technological advances as well as security policymakers' increasing demands have led to the ever-expanding reach of governmental authorities in utilising DNA extraction, analysis and storage. This international trend toward using more genetic information in police investigations has resulted from waves of technological innovation, each demanding the accommodation of existing legal frameworks and each raising new social and ethical concerns (Wienroth et al., 2014; M'charek, 2016).

When DNA fingerprinting was first introduced to police work and as evidence in court in the mid-1980s, the controversies surrounding DNA evidence were mostly

1. Regulation 2016/679 of the European parliament and council of 27 April 2016 on the protection of natural persons with regard to the processing of personal data and on the free movement of such data, and repealing Directive 95/46/EC (General Data Protection Regulation)

2. Gesetz über genetische Untersuchungen bei Menschen (Gendiagnostikgesetz - GenDG), 31.07.2009 
technical in nature, concerning the handling of DNA samples by police and laboratory errors (Lynch, 2013). They were laid to rest by an effort of standardisation of sample collection and laboratory methods established by an international consensus committee during the 1990s (Wienroth et al., 2014). At the end of the first technological wave of forensic DNA analysis, DNA evidence was established as a promising investigative tool for law enforcement. As Michael Lynch writes, “'DNA' became an evidential superhero: a powerful, even unassailable, agent of truth and justice" (Lynch, 2013, p. 66). DNA evidence became infallible in the mind of the public as well-not only in law enforcement and legal settings, but also through the depiction of criminal cases in the media and works of fiction. Scholars have described this phenomenon as the "CSI effect", referencing the American television series CSI: Crime Scene Investigation (2000-2015). Here, a variety of forensic science methods are represented as extremely powerful, fast and effective. Notably, while the series' unrealistic representation of computer software that can turn a few pixels into sharp photos has gained ridicule in the world of internet memes (Anon, 2015), similarly exaggerated representations of DNA technology have steered relatively clear of criticism. The CSI effect was originally termed by journalists to describe how jurors' expectations based on forensic evidence are shaped by its media representation (Cole \& Dioso-Villa, 2007). Later, the phenomenon was picked up by social scientists specifically in the context of forensic DNA technology (e.g. Machado \& Costa, 2013). Various case studies have shown that not only laypeople are influenced by the effect, but also those who are most affected by forensic DNA technology: convicts in interviews described DNA as "exceptionally powerful”, "something larger than 'just' a forensic technology" (Prainsack \& Kitzberger, 2009, pp. 52-53). Similarly, criminal justice practitioners, jury members and those involved in the criminal justice system have changed their verdict requirements (Wise, 2010). Even many defence lawyers consider DNA so infallible that they often relinquish their right to review the laboratory reports in question, accepting DNA results-or rather, their interpretation by police officials - as truth (Bliwier, 2017).

Since DNA has been widely established as an "evidential superhero", a new DNA technology has left its developmental stage behind and boldly entered the realms of law and police investigations: it is used to infer externally visible characteristics of an unknown person from their DNA markers. This technology is mostly called "forensic DNA phenotyping" (FDP) (Kayser, 2015; Wienroth et al., 2014) or sometimes a "DNA composite sketch" or "composite profile"; it has also been translated into other languages, such as the German genetisches Phantombild ("genetic facial composite"), a designation suggesting that the technology would have the same 
accuracy as artist drawings based on eyewitness reports of a suspect (e.g. VISAGE, 2020; KKWT/ED and Bundeskriminalamt, 2017). The American company Parabon NanoLabs also presents its product as a "composite sketch" or a photographic "snapshot" (Parabon NanoLabs, 2018). Often subsumed under this concept is the analysis of information termed "bio-geographical ancestry" (BGA) - the analysis of certain human genetic markers, so-called ancestry informative markers, that have discernible geographic distribution patterns. BGA is not a visible trait and therefore by definition is not "phenotyping". Because it is discussed in the same context and sometimes confused in the debate-an issue we will explore later-we will use "extended DNA analyses" (EDNA) as an umbrella term for all DNA-analysing technology that goes beyond conventional DNA fingerprinting.

While EDNA also uses DNA markers and partly draws on the already established DNA sequences of genetic fingerprinting, it generates a whole new set of data protection and privacy issues. And while the promise of DNA analysis in police investigations until now was to render individualised profiles of suspects, EDNA instead targets larger groups of individuals that are then profiled as potential suspect populations (M'charek, 2008; M'charek et al., 2020).

Tracing these issues and the shifting targets of criminal investigation, this article focuses in particular on the intersection of racism and sexism. In doing so, we will lay out how these suspect populations are inevitably racialised groups in European, white-majority societies like Germany and how this technology systematically targets minorities. To show these mechanisms at work, we begin by delineating the technical differences between conventional DNA profiling and EDNA that are important to understanding the specific data protection and societal problems that arise from this new technology.

Firstly, there are issues with the development of the technology itself: the basis of EDNA technology is the classification of humans along racialised categories, the "molecular" or "genetic reinscription of race" (Duster, 2006; El-Haj, 2007) already ingrained in studies from the field of populations genetics. Secondly, we will discuss issues surrounding its application in police investigations in the few publicised cases in which EDNA technology was applied in Germany. And thirdly, we will analyse the public debates that have led to the introduction of EDNA in Germany, further illustrating how discrimination based on race and sex is deeply entangled with the technology. While other researchers have frequently pointed out the dangers of racialisation, discrimination and stigmatisation (Duster, 2006; Bliss, 2008; Gannett, 2014; Skinner, 2020; Machado \& Granja, 2020; M'charek et al., 2020), we want to move a step further by shedding light on how claims of protect- 
ing women from violence play a particular role in this debate. Although this argument has already been in the spotlight of German debates surrounding the introduction of controversial DNA technology, in this most recent debate, issues of racialisation and sexism intersect and reinforce each other.

With our threefold focus on technologies, practices and public discourse, we want to investigate the specific co-production (Jasanof, 2004) of EDNA technology and society-meaning, how this technology emerges and is embedded in a specific social context. We combine methods of document analysis (Mayring, 2016) and discourse analysis (Jäger, 2001). As sources, we use a selection from relevant scientific papers in a variety of fields, media articles, legislative documents and expert statements that have been prominent in the public and academic debates surrounding the recent introduction of EDNA in Germany. We will build our argument mainly on examples, debates and laws in Germany, but we also will refer more briefly to similar processes in other European countries.

\section{The use and limits of extended DNA-Analyses}

Conventional forensic DNA analysis for identification purposes focuses on specific hyper variable regions in the human genome containing short tandem repeats (STR). STR are patterns of identical short DNA base pair repeats which can be found on several regions of each chromosome. They are expected to be highly variable between unrelated people (Dettmeyer et al., 2019). As so-called "non-coding" sequences, they do not contain structural information to build proteins and were therefore thought not to influence the characteristics of a person. Thus, it was thought that STRs can be analysed to match DNA traces to individuals without revealing additional information, e.g. about the person's health status. The German Federal Constitutional Court ruled in 1995 that DNA analysis does not pose a danger to human dignity if only the non-coding part of the DNA is analysed. However, to analyse the coding part of DNA would be an invasion of the "core of personality" (Kernbereich der Persönlichkeit) of the person in question. Scientifically, the legal differentiation between information-rich coding and information-free non-coding sequences has since been called into question. The non-coding sequences, formally dismissed by geneticists as "junk DNA" because their function was unknown, are now thought to play a role, e.g. in gene regulation. Forensic experts have stated that STR markers can be used to gain probabilistic information about personal information (Feuerlein \& Potthof, 2005; Kayser, 2015). The differentiation has also been weakened on a legal level. Since 2004, German police are allowed to determine chromosomal sex from DNA traces. The decision set a precedent for gaining 
personal information from the DNA of unknown persons. In any case, German law has never explicitly differentiated between non-coding and coding DNA in regulating the use of DNA analysis.

The identification of a person with a DNA trace at a crime scene can only take place if the comparative DNA is already stored in a police database or if a suspect is forced by a court to provide a DNA sample. In order to identify a person from a larger group based on a DNA trace, the police can execute dragnets in which hundreds or thousands of people are asked to provide their DNA voluntarily. Of course, the success of this measure relies on the participation of the suspect due to either goodwill or social pressure and, possibly, a lack of knowledge regarding DNA. To reduce these limitations, the German police is also allowed (since a criminal law reform in $2017^{3}$ ) to identify suspects through their relatives by searching for partial matches within dragnet databases; this technique is called familial searching. This method, however, only works if the relatives of the unknown suspect participate in the dragnet. Thus, to broaden the information gained from DNA evidence, forensic geneticists have been investigating the possibility of using coding DNA to predict unknown suspects' externally visible characteristics, age and BGA. Unlike the comparison of DNA sequences involved in STR matching, the prediction of complex traits is much more challenging.

As it turns out, DNA is potentially a quite precise tool for identification and determination of close biological kinship, but it is a less reliable tool when DNA sequences are not compared to each other and instead phenotypic characteristics are being inferred from these sequences. Achieving a similarly high degree of certainty, as in STR matching, is impossible for the prediction of most characteristics, and it will continue to be in the future. This is because-outside of a few known conditions caused by single base mutations, like sickle cell anaemia or Tay-Sachs disease - most traits are regulated by complex genetic networks, highly susceptible to environmental factors and thus difficult to predict from DNA alone. The phenotypic trait "height", for example, was investigated in a large genome-wide association study (GWAS) with the aim of determining genetic variations that statistically correlate with this trait. However, the 180 genetic loci most associated with height could only account for $10 \%$ of measurable phenotypic variation (Lango Allen et al., 2010). Since pigmentation appears to be a comparatively less complex trait, the colours of hair, eyes and skin are "the best and currently the only examples of practical FDP" (Kayser, 2015, p. 34). However, this does not mean that the prediction of these traits is an easy task. In a widely cited review paper, Kayser lists 31 
genetic variants that were associated with effects on skin colour phenotype in previous GWAS (Kayser, 2015). Even more complex is the development of a mere statistical association into a reliable predictive test that is applicable under real life conditions. This becomes clear, for example, when one looks at the forensic tool "HIrisPlex-S", which was developed by Kayser's team to simultaneously determine eye, hair and skin colour of a person based on 41 DNA variants (Breslin et al., 2019). While its creators report that this performed "reasonably well", HIrisPlex-S's reliability is apparently highly variable depending on the tested cohort. In a study with a Brazilian cohort, "except for dark to black color, the tool consistently fail[ed] in determining skin phenotypes" (Carratto et al., 2019).

\section{Genetic technology as another tool of racialisation}

In September of 2019 at the Annual Meeting of the German Zoological Society in Jena, zoologists and human geneticists declared in a statement that the concept of human races ("Menschenrassen") is not biologically meaningful, that it is a result of racism and that "the largest genetic differences are found within populations and not between them" (Fischer et al., 2019). Here, the authors reiterate criticisms of biological concepts of race that have been articulated since the beginning of the 20th century. For instance, this critique was also prominently formulated in two UNESCO declarations shortly after the end of the Second World War: "For all practical social purposes 'race' is not so much a biological phenomenon as a social myth" (UNESCO, 1950, p. 8). Nonetheless, biological concepts of race have often been adopted and reformulated despite the many critiques. These concepts are thus by no means obsolete and have even re-emerged in new forms with the advent of genetic research. Computer analysis is supposed to identify the "real genetic makeup" of a person in what the sociologist Troy Duster calls a "molecular reinscription of race" now seemingly independent from social categories (Duster, 2015).

Researching biological differences between racially, ethnically or regionally divided groups is still a wide field of research in population genetics, medicine and forensic genetics. Furthermore, even when researchers avoid distinct racial categories and instead conceptualise human variability as a continuous distribution of genetic traits around the globe, many still distinguish human populations as "discrete panmictic units" within this distribution (Gannett, 2003). In her study of the Human Genome Diversity Project (HGDP), Reardon describes the many factors that play into the construction of these units. In 1992, the HGDP started to gain knowledge on human genetic diversity and migration patterns by sampling populations 
around the world. Populations appear to be highly variable depending on the research question, whether certain groups could be accessed and the scientists' preconceived idea on what constitutes the unit in question (Reardon, 2004). The German debate on forensic applications of BGA mirrors the problems within academic research on population genetics regarding how to define separate populations. While proponents of EDNA insist on the objectivity of genetic analyses, the flexible definition of what even constitutes BGA reveals the pitfalls of attempting to draw conclusions based on these analyses. "Ethnicity", "ancestry" and "appearance" are terms many use interchangeably: the Association of German Criminal Investigators (BDK), which strongly favours the use of EDNA, described how using "special markers, forensics can classify a specific ethnicity or region of origin with high probability" (Bund Deutscher Kriminalbeamter, 2017, p.7, our translation). In a hearing at the Federal Ministry for Justice in 2017, Kayser stated that BGA was "a better possibility to analyse skin colour than current skin colour tests" (Schultz and Bartram, 2017, p. 72). On the same occasion, Ingo Bastisch, leader of the BKA laboratory, described BGA as externally visible and said it was easy to infer ancestry and ethnicity from the appearance of a person (Schultz and Bartram, 2017). This wrong representation and confusion are passed on to the political and public realm, where the different interpretations of what BGA means perhaps speak to the divergent interests in what information the technology should reveal. The often-voiced desire to determine the "ethnicity" of a person-a social category-using DNA analysis points to another problematic aspect of EDNA: ancestry and traits like skin colour are decidedly not socially neutral classifiers. Anti-racist and minority rights organisations have been warning of the discriminatory effect the technology poses when police investigations "amplify or incite discrimination or even race baiting" by "vague and error-prone analyses of external characteristics"4 (Gen-ethisches Netzwerk, 2017, p. 2, our translation). The German government also recognised this danger in a bill from October 2019 that introduced the analysis of hair, eye and skin colour as well as age to the code of criminal procedure (BMJV, 2019). Its authors ask to consider that "attribution of the trace to a member of a minority must not lead to misuse of this fact for the purpose of racist propaganda and agitation" (BMJV, 2019, p. 31, our translation). However, the bill includes no regulation designed to implement this advice. It argues that, with respect to the risk of discrimination, the analysis of externally visible characteristics is "no different than the release of investigation results achieved by witness testimony or video recordings" (BMJV, 2019, p. 30, our translation).

4. As an employee of Gen-ethisches Netzwerk e.V., the author of the present paper Isabelle Bartram has co-written this statement. 
In an interview on the law reform, the German Minister of Justice Christine Lambrecht also advocated for the equal consideration of both witness statements and DNA analysis (Rath, 2019b). Upon closer inspection, though, the comparison of DNA analysis to witness statements or video surveillance falls short. The result of EDNA analysis is not a "genetic photofit" of suspects. It is a statistical approximation of three components of a face, none of them describing a size or shape. It also cannot deliver any contextual information, such as clothing and behaviour, or individual traits like a suspect's posture, scars or haircut. The EU-financed research project VISible Attributes Through GEnomics - VISAGE, which has the goal of "widespread application in routine forensic casework" of EDNA technology, explains their use of the term "DNA composite sketch" as follows: "a sketch, by definition, is something unfinished, not something precise - which reflects what forensic DNA phenotyping (FDP) does" (VISAGE, 2019, n.p.). The results of EDNA are unable to identify a single individuum in the way that DNA fingerprinting would since the information includes only approximations of a few characteristics and is considered imprecise even by technology developers. Instead, EDNA analyses point to large groups of people who have, for example, a common skin colour and turn them into suspect populations (M'charek, 2008). Considering the undeniable privacy intrusion introduced by governmental DNA testing, proponents of EDNA often argue that the majority of the population could be shielded from widespread genetic dragnets if the investigation can be focused on a smaller circle of suspects instead. Thus, while the majority can remain invisible, minority groups will arise more frequently as targets in police investigations (Queirós, 2019). This means that the vulnerability of minorities is automatically increased by EDNA application, independent of the existing or non-existing biases of the individual police officer.

This dynamic has already played out in past cases where EDNA was applied-in Germany and beyond. The so-called Phantom of Heilbronn was a DNA profile of an unknown woman that was found at several crime scenes in Germany, France and Austria. One of them was the murder of police officer Michèle Kiesewetter, who was shot in 2007 in Heilbronn. When BGA was performed in Austria, it revealed a probable "Eastern European" ancestry of the DNA trace. The synergy of systematic antiziganism and a strong belief in DNA technology led to an intense focus on the Roma and Sinti community on the part of the police (Kleffner, 2017; Lipphardt, 2017). We know today that Kiesewetter was killed by a member of the German right-wing extremist terror group Nationalsozialistischer Untergrund (NSU). The focus of the investigation, skewed by racial bias and DNA, not only wrongfully subjected hundreds of people to the police investigation. It also left minorities more vulnerable by reversing the roles of victim and culprit. Should EDNA become a 
routine police tool, members of minority groups will be increasingly burdened with participation in investigative measures such as DNA dragnets and thereby will be the object of genetic racial profiling. This in turn may fuel the racist imaginary of the "dangerous other" in the mind of the public as well as the police (Momsen, 2017).

In the case of the Phantom of Heilbronn, the racist media coverage of the investigation reinforced the stigmatising imagery of "criminal Roma clans", and this effect that could not be reversed even after it became clear that the police had a false investigative lead. Two recent cases in Germany underline the idea that, in contrast to minority groups, the White majority will be unaffected by the introduction of EDNA. In one case of a serial rapist, named the "Allgäuer Triebtäter" (the sex offender of Allgäu), the EDNA analysis revealed a "European" BGA (Rath, 2019a). In a second case, called "Isarmord" (Isar murder), EDNA predicted the unknown suspect to have brown or light brown hair, brown eyes and medium skin colour and a BGA from Europe with probable ancestry in northern Ukraine, Russia or Belarus (Hans, 2020). In both cases, the predicted traits are shared by large parts of German society and the police therefore did not consider the EDNA results useful. Thus, there was no further investigation involving all people matching this broad description.

\section{"Protection of women" as a "Trojan horse" for the expansion of DNA surveillance technology}

In Germany, like in other countries, controversial surveillance policy changes often follow highly publicised, precedent-setting cases (Weitz \& Buchanan, 2017). Cases of femicides and sexual violence against women and girls have been especially significant in making legal changes that justify the further extension of state authority and the use of DNA in investigative proceedings. In 1989, the BKA announced their continued use of DNA profiles, despite an opposing vote by the legal committee of the German federal government. Officials declared that DNA would only be used in serious criminal investigations and that no database would be created to store the profiles (Wagenmann \& Schultz, 2017). After nine years of DNA use in police investigations without legal basis, the law Strafverfahrensänderungsgesetz DNA-Analyse (Criminal Procedure Amendment Act for DNA analysis) was passed in 1997, but it allowed only paternity testing of suspects and imposed strict requirements for privacy protection and data protection rights; collected DNA material and data had to be destroyed after the investigation. In the beginning of 1998, a central DNA database of the BKA was created on orders from Minister of the Interior Manfred Kanther, who welcomed this step to create a tool to catch sex 
offenders (Wagenmann, 2000). In the same year, voluntary DNA testing of 16,400 local men had revealed a match for a suspect in the rape and murder of a girl in northwestern Germany. Ronny Rieken confessed to murdering two girls and raping 14 more; the case proved the power of DNA evidence to the German public (Jüttner, 2007). The public outcry surrounding these brutal cases prevented a broad public debate about the legal basis and proportionality of DNA databases in law enforcement. The DNA-Identitätsfeststellungsgesetz ${ }^{5}$ (DNA-IFG, DNA identification law) was passed a half year later in 1998 to legitimise (retrospectively) the BKA's collection of DNA profiles (Steven 2005). The law first introduced § $81 \mathrm{~g}$ to the code of criminal procedure, which allowed body cells to be collected from suspects of "serious crimes" to check their identity through genetic analysis. Further amendments to the article were passed in the following year. While the general public remained silent, a group of several feminist organisations criticised the development: in 1999, they published a statement opposing the notion that DNA technology offered an adequate tool for protecting victims of sexual crimes (Deutscher Juristinnenbund e.V et al., 1999). As experts in matters of protecting women and children against violence, they weighed the expected benefits against large potential damages: they feared that the focus on "the foreign (or unknown) repeat offender" would divert attention from the many women and children who experience daily violence-not at the hands of strangers, but of those in their immediate social environment. Therefore, they argued that sexual crimes were used as a "Trojan horse" to introduce DNA technology. Arguing from the victim's perspective, the authors also criticised that the long-term storage of crime scene DNA traces meant that victims' right to privacy was "unnoticed and carelessly" violated as well (Deutscher Juristinnenbund e.V. et al., 1999, our translation).

Four years after the DNA-IFG, further high impact DNA legislation was introduced, again justified by the promise of more effective criminal prosecution of sexual crimes. The law Gesetz zur Änderung der Vorschriften über die Straftaten gegen die sexuelle Selbstbestimmung ${ }^{6}$ (law to amend the provision on crimes against sexual self-determination) in 2003 turned exhibitionism or "insults with a sexual motive" into "serious crimes", allowing for DNA swabs of suspects and the storage of their DNA profiles. The responsible lawmakers based this decision on an empirical study from the University of Göttingen that demonstrated "that less serious crimes often stand at the beginning of a criminal career, which can end in serious crimes" (Bundestag, 2003, our translation; see Steven, 2005). However, the same numbers also

5. Gesetz zur Änderung der Strafprozeßordnung (DNA-Identitätsfeststellungsgesetz), 07.09 .1998

6. Gesetz zur Änderung der Vorschriften über die Straftaten gegen die sexuelle Selbstbestimmung und zur Änderung anderer Vorschriften, 27.12.2003 
show that $98 \%$ to $99 \%$ of those accused of smaller crimes will not commit violent crimes later in life and thus would be wrongfully included in this preventative measure (Steven, 2005). Two years later, the legal definition of "serious crimes" was expanded to include the repetition of-or prognosis of committing-less serious offences (like theft or insults). Again, proponents invoked empirical criminology studies to argue for this revision: Bernd Carstensen, vice chairman of the BDK, cited studies that "prove that 70 percent of sexual criminals commit crimes other than sexual offences in the course of their criminal career" (Carstensen, 2005, our translation). In his opinion, swabbing suspects of small offences would therefore "strongly protect possible victims of sexual crimes" (Carstensen, 2005, our translation). This reasoning mirrored developments in other countries like the UK, where the expansion of DNA use was also based on the theory that the typical trajectory of a violent criminal career was characterised by recidivism and an escalation of severity (Lynch \& McNally, 2009). UK police representatives recommended getting as many offenders as possible in the database early in their criminal career. In a recent article in a police trade journal, Matthias Frey, former leader of the permanent crime unit at the Berlin police department no. 5, describes a similar strategy of collecting as many DNA samples as possible (Frey, 2019). A further change in the German DNA law ${ }^{7}$ in 2005 made the aggressive pursuit of this objective possible: before, a judicial decision had to precede a DNA swab of a suspect, but following the revision, suspects could comply with a DNA swab on a voluntary basis. As a result of these two major changes, the central DNA database grew exponentially: during the previous 17 years, a total of 300,000 profiles had been collected, but with the new policy, it took only half this time to add another 500,000 profiles (Wagenmann \& Schultz, 2017). Today, the DNA database of the BKA contains 870,000 profiles of known persons and 34,000 trace profiles. Since profiles of people must be reviewed for deletion after 10 years ( 5 years for adolescents) ${ }^{8}$, the growth has slowed down in recent years.

Until 2019, the webpage of the BKA displayed a statistic that showed how many DNA matches the database had achieved so far for given crimes (BKA / Webarchive, 2018). It is important to note that a DNA match does not mean a successful investigation or a conviction of the person in question. In the beginning of 2019 (31.03.2019), more than $77 \%$ of the 228,221 matches between profiles of a known person and a crime scene trace were made in the context of theft. Less than $1.8 \%$ concerned "criminal offences against physical integrity" and less than $1.8 \%$ 
“crimes against sexual self-determination" (our translations). As the women's organisations had anticipated 20 years earlier, crime statistics do not show a decline in rape in Germany since the expansion of the BKA DNA database (Statista, 2019). While the numbers from recent years may have increased because of changes in the law on sexual offences ${ }^{9}$ in 2016 and the \# metoo movement, other statistics paint a similar picture. In 2018, every third day a woman was murdered by her partner or former partner in Germany, according to a report from the Federal Ministry of Family Affairs, Senior Citizens, Women and Youth (BMFSFJ, 2019). Considering the estimated number of unreported cases, every third woman in Germany experiences violence from partners or other people in her lifetime. According to the recent crime statistics report from the BKA, the overall numbers on violence against women in Germany have been steadily increasing in recent years (BKA, 2018). Proponents of the ever-expanding use of DNA technology by police argue that they want to protect women. If one takes this argument seriously, then this technology, an incredibly resource-intensive process, does not appear to be an effective or efficient tool. As investigative DNA technology-supposedly intended to protect women-has been growing, the rates of violence against women have only worsened.

\section{Migration debate as a driver for more surveillance}

Precedent cases of sexual crimes continued to play a leading role in the latest discussions that preceded the next major expansion of DNA authority at the end of 2019. The recent policy developments are the result of an intense public debate following two rapes and murders of young women in 2016 in the south of Germany (Lipphardt, 2018). Not all cases of sexual violence seemed to be equally suitable to argue the necessity of EDNA technology. In her inaugural talk at a symposium on EDNA, Anja Reuss, representative of the Central Council of German Sinti and Roma, pointed out that the equally brutal sexual murder of Chinese student Li Yangjie in Dessau that same year "did not trigger a nationwide debate or demands for measures in the security apparatus" (Reuss, 2018, p. 2, our translation). Even though most proponents insist that DNA analysis is objective and not directed against minorities, the German debate on EDNA has been entangled with the migration debate surrounding the so-called "Flüchtlingskrise" (refugee crisis) in 2015 and 2016.

Demands to legalise EDNA were not new in 2016. Lipphardt has analysed how the geneticist Manfred Kayser has been a central figure in the debate. When asked by 
journalists, Kayser had been characterising the German DNA legislation as "outdated" for some time already (Lipphardt, 2018). But concerns about data protection and the state of the technology still loomed large in the public and lawmakers' minds. In October 2016, student Maria L. was raped and murdered in Freiburg. In the next month, the sexual murder of Carolin G. by an unknown perpetrator occurred nearby. The first connection between these crimes and EDNA legislation was made in a flyer distributed by the right-wing group "Bund gegen Anpassung" in early November 2016 that postulated, "nothing is easier to determine from DNA than race" (our translation) and suggested that the perpetrator was protected from state authority due to his race. A few days later, articles in different newspapers-in more sophisticated language-communicated the same sentiment: one suggested it would be possible to reduce the circle of suspects using DNA analysis of ancestry, hair, eye colour and height, but that this approach was not allowed out of "misunderstood political correctness" (Krautkrämer, 2016, our translation). In another newspaper on the same day, an article criticised that $\$ 81 \mathrm{~g}$ was too limited to use DNA evidence to analyse "ethnic ancestry" and focus the investigation (Sodt, 2016, our translation). The next day, a long article in the prominent local newspaper Badische Zeitung described how DNA as "witness in the laboratory" could tell us with "near absolute certainty from which part of the world the murderer of Maria L. comes" but was unfortunately restricted by current law (Röderer, 2016, our translation). In this article, Manfred Klumpp, a BDK representative, attested to how helpful the analysis would be since "every detail, every hint helps" and EDNA would "increase the chances" of finding the murderer of Maria L.

Through their analysis of news and media before and after these sexual murders, Weitz and Buchanan have shown how EDNA technology was presented as a "technological fix" in a debate driven by fear (2017). Ultimately, both cases were solved by conventional investigation techniques. But instead of stopping the demand for EDNA legalisation (a method that was apparently expendable), the political process was only accelerated when it turned out that Maria L's murderer was an immigrant. This makes clear that the media response was driven by and drawing upon existing racist fear in the public.

On 3 December 2016 at a press conference following the arrest of a suspect who was a refugee from Afghanistan, Baden-Wuerttemberg's ministers of justice and interior, Guido Wolf and Thomas Strobl, demanded the legalisation of EDNA and announced their respective legislative plans (Müller, 2016b). Two days later, all factions in the state assembly in Stuttgart supported an expansion of DNA use for investigations (Müller, 2016a). Freiburg chief of police Berhard Rotzinger stated how 
EDNA "would have helped greatly" to find the murderer of Maria L., as "with such a 'photofit' from the laboratory", suspects could have been removed much earlier (Hupka, 2016, our translation). A group of interdisciplinary scientists from several German universities-today called WIE-DNA-was motivated by these quick political developments (which generated unfounded technological promises) to publish an open letter (Lipphardt et al., 2016). They called for a consideration of the ethical and social ramifications of EDNA as well as its current technological limitations. They also were the first scientists to object publicly to the idea that EDNA would have helped to catch the killer of Maria L. Other experts have since agreed that in cases like these, in a large, diverse city like Freiburg, EDNA is not a useful tool to limit the circle of suspects. Much later, even Kayser agreed that "it was the wrong case to make that claim" (Vogel, 2018). His comment in an English scientific journal did not find its way back into the German debate, in which Kayser did not explain the limitations of EDNA analyses in a similar fashion. The public debate in Germany also elided the fact that, so far, no publicly known cases exist in which the analysis of externally visible characteristics has helped to solve a crime; globally, not even a dozen cases are known in which the analysis of BGA assisted investigators (WIE-DNA, 2019).

In May of 2018, despite protest from the public and the unfinished scientific debate, legalisation of EDNA was passed in Bavaria as part of a new state police law $^{10}$ (Bartram, 2018). BGA, hair, eye, skin colour and age of an unknown person can now be analysed to serve police work as a measure of "protection against threats" (Gefahrenabwehr). Around the same time, the coalition parties of the Christian Democrats (CDU) and the Social Democrats (SPD) agreed to introduce the analysis of hair, eye and skin colour as well as age on the federal level into the code of criminal procedure as part of a plan to "modernise" the code. As part of a "conscious decision", BGA was not included in these plans (Rath, 2019b). According to Minister Lambrecht, BGA can only reliably predict continental ancestry and therefore the fear is warranted that BGA would put large groups of people under general suspicion (Rath, 2019b). However, as the WIE-DNA initiative has pointed out, the analysis of traits like skin colour bears a danger of discrimination against minorities much like BGA analysis does (WIE-DNA, 2019). Nevertheless, the law reform was passed in November 2019.

The dynamics of the Kölner Silvesternacht of 2015 and the German asylum law debate are another example of a quick legislative process following an emotional debate about sexual violence; these anxieties are embedded in and reinforced by an 
existing public discourse shaped by right-wing populism (Klemm, 2017). Boulila and Carri (2017) describe how reported sexual assaults during New Year's Eve 2015/2016 in Cologne sparked a turning point in the public discussion on migration. Feminist demands for the acknowledgement of sexual violence and misogyny as deep-seated problems in German society were met with ignorance or aggression by mainstream and right-wing actors (Boulila \& Carri, 2017, see also Hark \& Villa, 2018). The same actors, however, suddenly considered the need to protect women the highest priority and a fundamental German value once the perpetrators were identified as male migrants. The debate led to a long-overdue amendment of the legislation on sex offences, which implemented the Convention on Preventing and Combating Violence against Women and Domestic Violence from 2011 (Istanbul Convention) (Boulila \& Carri, 2017). At the same time, the portrayal of the dangerous male migrant led to a change of the German Residence Act, making sexual assault a reason for deportation. Migrant organisations have criticised that, while the legal change might protect German women from sexual violence, it simultaneously worsens the situation for female migrants who experience domestic violence, since their own right to stay can be tied to their abuser (McCaskill, 2018). Similarly, due to their intersectional experiences (Crenshaw, 1991), female migrants and women of colour are doubly marginalised by EDNA legalisation. First, it is falsely advertised as a solution to violence against all women, who might become even more vulnerable since the debate on EDNA diverts attention, as well as resources, from the fact that most violence happens in the private realm. Additionally, female migrants and women of colour are negatively affected by the racist imagery of the "criminal immigrant" that is amplified and reinforced in the debates on EDNA and that harm all migrants and people of colour.

\section{Conclusion}

By investigating EDNA technology in relation to the social practices and public discourse around it, we first illustrated how the false representation and confusion of "ethnicity", "ancestry" and "appearance" are passed on to the political and public realm. We also demonstrated how EDNA application automatically increases the vulnerability of minorities because it is designed to look for rare traits; this in turn may fuel the racist imaginary of the "dangerous other" in the mind of both the public and the police. We then argued that the "protection of women" was used as a "Trojan horse" for the expansion of DNA surveillance technology and reconstructed how racist images of the migrant rapist played out in the migration debate and became a driver for more surveillance. 
Sexism and racism intersect once again in the current discussions on EDNA, building on existing public fears of unknown male migrants as threats to white German women. These fears belong to a long tradition of demonising men of colour, such as the myth of the black rapist and construction of white female victimhood that fuelled racist lynchings (Davis, 1981). In this current iteration, controversial DNA technology is promoted as a solution. Instead of increasing safety, genetic racial profiling will likely only worsen unacknowledged institutional bias against minorities and racial profiling in police work in Germany while failing to protect all women against violence (Momsen, 2017; Sarbo, 2019). Hostile dynamics may emerge in conjunction with an unquestioned trust in DNA technology. Such strife will increase the vulnerability of already marginalised demographic groups rather than protecting them. Furthermore, the public discourse surrounding EDNA risks marginalising migrants and German people of colour further because it reinforces beliefs in biological "truths" of human differences and categories inscribed into our DNA-beliefs we had supposedly overcome.

\section{References}

Anonymous. (2015). Zoom and Enhance, Know Your Meme. https://knowyourmeme.com/memes/zoo m-and-enhance

Bartram, I. (2018). DNA-Analyse zur Gefahrenabwehr. Gen-ethischer Informationsdienst, 245, 32-33.

B.F.D.I. (2003). Entschließung der Konferenz der Datenschutzbeauftragten des Bundes und der Länder. Der Erweiterung Der DNA-Analyse Augenmaß Bewahren. https://www.bfdi.bund.de/SharedDocs/Pu blikationen/Entschliessungssammlung/DSBundLaender/69DSK-EntschliessungZurBundesratsinitiati veMehrererLaenderZurAusweitungDerDNA-Analyse_KeineGleichsetzungDerDNA-AnalyseMitDemFin gerabdruck.html

B.K.A. (2018). Partnerschaftsgewalt. Kriminalstatistische Auswertung - Berichtsjahr 2018 [Report]. http s://www.bka.de/SharedDocs/Downloads/DE/Publikationen/JahresberichteUndLagebilder/Partnersch aftsgewalt/Partnerschaftsgewalt_2018.pdf

B.K.A. / Webarchive. (2018). DNA-Treffer Statistik. Bundeskriminalamt. https://web.archive.org/web/2 0180615163025/https://www.bka.de/DE/UnsereAufgaben/Ermittlungsunterstuetzung/DNA-Analys e/DNAstatistik/dnaStatistik_node.html

Bliss, C. (2008). Mapping Race through Admixture. International Journal of Technology, Knowledge and Society, 4(4), 79-83. https://doi.org/10.18848/1832-3669/CGP/v04i04/55899

Bliwier, T. (2017). Überschätztes Beweismittel? freispruch, 11. http://www.strafverteidigervereinigun gen.de/freispruch/texte/bliwier\%20Heft11.pdf

B.M.F.S.F.J. (2019). Gewalt gegen Frauen - Zahlen weiterhin hoch Ministerin Giffey startet Initiative „Stärker als Gewalt.. Bundesministerium für Familie, Senioren, Frauen und Jugend. https://www.bmfsfj.d e/bmfsfj/aktuelles/presse/pressemitteilungen/gewalt-gegen-frauen---zahlen-weiterhin-hoch-minis 
terin-giffey-startet-initiative--staerker-als-gewalt-/141688

Regierungsentwurf eines Gesetzes zur Modernisierung des Strafverfahrens, Bundesministerium der Justiz und für Verbraucherschutz (2019) (testimony of B.M.J.V.). https://www.bmjv.de/SharedDocs/Ge setzgebungsverfahren/Dokumente/RegE_Modernisierung_Strafverfahren.pdf

Boulila, S. C., \& Carri, C. (2017). On Cologne: Gender, Migration and Unacknowledged Racisms in Germany. European Journal of Women's Studies, 34(3), 283-293. https://doi.org/10.1177\%2F1350506 817712447

Breslin, K., Wills, B., Ralf, A., Ventayol Garcia, M., Kukla-Bartoszek, M., Pospiech, E., Freire-Aradas, A., Xavier, C., Ingold, S., de La Puente, M., van der Gaag, K. J., Herrick, N., Haas, C., Parson, W., Phillips, C., Sijen, T., Branicki, W., Walsh, S., \& Kayser, M. (2019). HIrisPlex-S system for eye, hair, and skin color prediction from DNA: Massively parallel sequencing solutions for two common forensically used platforms. Forensic Science International: Genetics, 43, 102152. https://doi.org/10.1016/j.fsige n.2019.102152

Bund Deutscher Kriminalbeamter. (2017). Wahlprüfsteine Zur Bundestagswahl 2017. https://www.bd k.de/der-bdk/aktuelles/bundestagswahl-2017/Wahlprufsteine

Carratto, T. M. T., Marcorin, L., Debortoli, G., Silva, G. V., Fracasso, N. C. A., Oliveira, M. L. G., Pereira, A. L. E., Silva, A. B. C., Donadi, E. A., Simões, A. L., Castelli, E. C., Norton, H. L., Parra, E. J., \& MendesJunior, C. T. (2019). Evaluation of the HIrisPlex-S system in a Brazilian population sample. Forensic Science International: Genetics Supplement Series, 7(1), 794-796. https://doi.org/10.1016/j.fsigss.201 9.10.180

Carstensen, B. (2005). DNA-Analysen ausweiten? Junge Freiheit. https://jungefreiheit.de/debatte/200 5/dna-analysen-ausweiten

Cole, S. A., \& Dioso-Villa, R. (2007). CSI and its Effects: Media, Juries, and the Burden of Proof. New England Law Review, 41(3), 435-470.

Crenshaw, K. (1991). Mapping the Margins: Intersectionality, Identity Politics, and Violence against Women of Color. Stanford Law Review, 43(6), 1241. https://doi.org/10.2307/1229039

Davis, A. (1981). Women, Race \& Class. New York Random House.

Dettmeyer, R., Veit, F., \& Verhoff, M. (2019). Forensische DNA-Analyse. In Rechtsmedizin (pp. 267-284). Springer.

Deutscher Bundestag. (2003). Bundesrat will DNA-Analyse bei allen Sexualstraftaten einführen. Webarchiv. http://webarchiv.bundestag.de/archive/2005/0113/bic/hib/2003/2003_030/03.html

Deutscher Juristinnenbund e.V. (1999). Gemeinsame Erklärung verschiedener Frauenverbände zur Errichtungsanordnung zur Einrichtung einer DNA-Analyse-Datei. Deutscher Juristinnenbund, 33. Kongress in Magdeburg vom 16. bis 18. September 1999, 33, 88-93.

Duster, T. (2006). The Molecular Reinscription of Race: Unanticipated Issues in Biotechnology and Forensic Science. Patterns of Prejudice, 40(4/5), 427-441. https://doi.org/10.1080/00313220601020 148

Duster, T. (2015). A post-genomic surprise. The molecular reinscription of race in science, law and medicine: A post-genomic surprise. The British Journal of Sociology, 66(1), 1-27. https://doi.org/10.1 $111 / 1468-4446.12118$

El-Haj, N. A. (2007). The Genetic Reinscription of Race. Annual Review of Anthropology, 36(1), 
Feuerlein, M., \& Potthof, C. (2005). Codierend-nicht-codierend. Interview mit Peter Schneider. Genethischer Informationsdienst, 170, 14-19.

Fischer, M. S., Hoßfeld, U., Krause, J., \& Richter, S. (2019). Jenaer Erklärung. Das Konzept der Rasse ist das Ergebnis von Rassismus und nicht dessen Voraussetzung [Declaration]. https://www.uni-jena.de/1 90910_JenaerErklaerung.html

Frey, M. (2019). Konsequente Erhebung freiwilliger DNA Personenproben als Basis für den Ermittlungserfolg. Die Polizei.

Gannett, L. (2003). Making Populations: Bounding Genes in Space and in Time. Philosophy of Science, 70(5), 989-1001. https://doi.org/10.1086/377383

Gannett, L. (2014). Biogeographical ancestry and race. Studies in History and Philosophy of Science Part C: Studies in History and Philosophy of Biological and Biomedical Sciences, 47, 173-184. https://d oi.org/10.1016/j.shpsc.2014.05.017

Gen-ethisches Netzwerk. (2017). Stellungnahme: Gegen die Erweiterung polizeilicher Befugnisse in der DNA-Analyse. https://www.gen-ethisches-netzwerk.de/pressemitteilungen/april-2017/25-organisati onen-fordern-keine-erweiterung-polizeilicher-befugnisse

Hans, J. (2020, March 5). Österreicher erstellen neues Gutachten zum Isarmörder: Ungeklärter Kriminalfall. Süddeutsche Zeitung. https://www.sueddeutsche.de/muenchen/muenchen-isarmord-gu tachten-1.4832679

Hark, S., \& Villa, P.I. (2017). Unterscheiden und herrschen: Ein Essay zu den ambivalenten Verflechtungen von Rassismus, Sexismus und Feminismus in der Gegenwart. Transcript.

Hupka, S. (2016, December 6). Freiburger Polizeichef: Mehr DNA-Befugnisse. Badische Zeitung. http s://www.badische-zeitung.de/suedwest-1/freiburger-polizeichef-mehr-dna-befugnisse--13069574 8.html

Jäger, S. (2001). Chapter 3: Discourse and Knowledge: Theoretical and Methodological Aspects of a Critical Discourse and Dispositive Analysis. In R. Wodak \& M. Meyer, Methods of Critical Discourse Analysis. SAGE Publications, Ltd. https://doi.org/10.4135/9780857028020

Jasanoff, S. (Ed.). (2004). States of knowledge: The co-production of science and social order. Routledge. Jüttner, J. (2007). Er ist schlicht und einfach nur böse. Spiegel. https://www.spiegel.de/panorama/jus tiz/der-fall-ronny-rieken-er-ist-schlicht-und-einfach-nur-boese-a-513506.html

Kayser, M. (2015). Forensic DNA Phenotyping: Predicting human appearance from crime scene material for investigative purposes. Forensic Science International: Genetics, 18, 33-48. https://doi.or g/10.1016/j.fsigen.2015.02.003

K.K.W.T./E.D. \& Bundeskriminalamt. (2017). Genetisches Phantombild (DNA-Phenotyping). http://ww w.innenministerkonferenz.de/IMK/DE/termine/to-beschluesse/2017-06-14_12/anlage-zu-top-27.pd f?_blob=publicationFile \&v=2

Kleffner, H. (2014). NSU und das »Phantom von Heilbronn«. Rassistische Ermittlungen gegen Roma und Sinti. In S. Schultz, T. Bliwier, \& Gen-Ethisches Netzwerk e.V (Eds.), Identität auf Vorrat: Zur Kritik der DNA-Sammelwut. Assoziation A.

Klemm, S. (2017). Der deutsche Asyldiskurs vor und nach der Silvesternacht 2015. Working Papers 
for Middle Eastern and North African Politics, 16, 1-66.

Krautkrämer, F. (2016, November 16). Politische Korrektheit kann tödlich sein. Junge Freiheit. http s://jungefreiheit.de/debatte/kommentar/2016/politische-korrektheit-kann-toedlich-sein

Lango Allen, H., Estrada, K., Lettre, G., Berndt, S. I., Weedon, M. N., Rivadeneira, F., Willer, C. J., Jackson, A. U., Vedantam, S., Raychaudhuri, S., Ferreira, T., Wood, A. R., Weyant, R. J., Segrè, A. V., Speliotes, E. K., Wheeler, E., Soranzo, N., Park, J.-H., Yang, J., ... Hirschhorn, J. N. (2010). Hundreds of variants clustered in genomic loci and biological pathways affect human height. Nature, 467(7317), 832-838. https://doi.org/10.1038/nature09410

Lipphardt, A. (2017). Das Phantom von Heilbronn. Freispruch, 11, 1-14.

Lipphardt, V. (2018). Vertane Chancen? Die aktuelle politische Debatte um Erweiterte DNA-Analysen in Ermittlungsverfahren* Berichte zur Wissenschaftsgeschichte, 41(3), 279-301. http s://doi.org/10.1002/bewi.201801900

Lipphardt, V., Lipphardt, A., Buchanan, N., Surdu, M., Toom, V., Weinroth, M., Mupepele, A.C., Bradbury, C., \& Lemke, T. (2016). Offener Brief zum kritischen Umgang mit Erweiterten DNA-Analysen in der Forensik. http://www.wie-dna.de/offener-brief

Lynch, M. (2013). Science, truth, and forensic cultures: The exceptional legal status of DNA evidence. Studies in History and Philosophy of Science Part C: Studies in History and Philosophy of Biological and Biomedical Sciences, 44(1), 60-70. https://doi.org/10.1016/j.shpsc.2012.09.008

Lynch, M., \& McNally, R. (2009). Forensic DNA Databases: The Co-Production of Law and Surveillance Technologies. In Handbook of Genetics and Society. Mapping the New Genomic Era (pp. 283-301). Routledge.

Machado, H., \& Costa, S. (2013). Biolegality, the Forensic Imaginary and Criminal Investigation* RCCS Annual Review, 5. https://doi.org/10.4000/rccsar.490

Machado, H., \& Granja, R. (2020). Emerging DNA Technologies and Stigmatization. In H. Machado \& R. Granja, Forensic Genetics in the Governance of Crime (pp. 85-104). Springer Singapore. https://do i.org/10.1007/978-981-15-2429-5_7

Mayring, P. (2016). Einführung in die qualitative Sozialforschung: Eine Anleitung zu qualitativem Denken. Beltz Juventa.

McCaskill, T. (2018). Gewaltschutzgesetz Und Beratungsstellen Im Kontext Migration. In M. Brazzel (Ed.), Was macht uns wirklich sicher? (pp. 68-72).

M'Charek, A. (2008). Silent Witness, Articulate Collective: DNA Evidence and the Inference of Visible Traits. Bioethics, 22(9), 519-528. https://doi.org/10.1111/j.1467-8519.2008.00699.x

M'Charek, A. (2016). Performative Circulations: On Flows and Stops in Forensic DNA Practices. Tecnoscienza, 7(2), 9-34.

M'charek, A., Toom, V., \& Jong, L. (2020). The Trouble with Race in Forensic Identification. Science, Technology, \& Human Values, 45(5), 804-828. https://doi.org/10.1177/0162243919899467

Momsen, C. (2017). DNA-Phenotyping und Racial Biases. freispruch, 11, 20-21.

Müller, A. (2016a). Alle Fraktionen für erweiterte DNA-Analyse. Stuttgarter Zeitung. https://www.stut tgarter-zeitung.de/inhalt.diskussion-ueber-fahndung-per-dna-alle-fraktionen-fuer-erweiterte-dna-a nalyse.b15aa633-56a7-45a2-ad3a-1e36a796f54d.html 
Müller, A. (2016b). CDU-Minister Wolf und Strobl. Vorstoß für Fahndung per DNA. Stuttgarter Zeitung. https://www.stuttgarter-zeitung.de/inhalt.cdu-minister-wolf-und-strobl-vorstoss-fuer-fahn dung-per-dna.6197df6c-3f29-43f9-82f2-e256239af5f5.html

Parabon Nanolabs. (2018). Prabon Snapshot. https://snapshot.parabon-nanolabs.com

Prainsack, B., \& Kitzberger, M. (2009). DNA Behind Bars: Other Ways of Knowing Forensic DNA Technologies. Social Studies of Science, 39(1), 51-79. https://doi.org/10.1177/0306312708097289

Queirós, F. (2019). The visibilities and invisibilities of race entangled with forensic DNA phenotyping technology. Journal of Forensic and Legal Medicine, 68, 101858. https://doi.org/10.101 6/j.jlm.2019.08.002

Rath, C. (2019a). Erweiterte DNA-Fahndung. Hat auch nichts gebracht. Taz. https://taz.de/!5612036

Rath, C. (2019b). Justizministerin zur DNA-Strafverfolgung: „Das ist keine Stigmatisierung!“. Taz. http s://taz.de/!5625314/

Reardon, J. (2009). Race to the Finish Identity and Governance in an Age of Genomics.

Reuss, A. (2018). Einführung zum Fachtag „Racial Profiling und erweiterte DNA-Analysen in Kriminalpolizeilichen Ermittlungen“. https://zentralrat.sintiundroma.de/download/8124

Röderer, J. (2016, November 17). Nach den Sexualmorden - was eine DNA-Analyse kann und was sie darf. Badische Zeitung. https://www.badische-zeitung.de/suedwest-1/nach-den-sexualmorden-w as-eine-dna-analyse-kann-und-was-sie-darf--129935568.html

Sarbo, B. (2019). Racial Profiling in Deutschland: Keine Frage individuellen Fehlverhaltens. Bürgerrechte \& Polizei/CILIP, 118-119, 110-114.

Schultz, S., \& Bartram, I. (2017). Erweiterte DNA-Analysen. Technische Aufrüstung mit rassistischen Verwicklungen. Bürgerrechte \& Polizei/CILIP, 113, 69-78.

Skinner, D. (2020). Forensic genetics and the prediction of race: What is the problem? BioSocieties, 15(3), 329-349. https://doi.org/10.1057/s41292-018-0141-0

Sodt, R. (2016, November 16). Aktenzeichen XY: Vergewaltigt und ermordet. Frankfurter Allgemeine. Frankfurter Allgemeine. https://www.faz.net/aktuell/gesellschaft/kriminalitaet/morde-i n-sueddeutschland-bei-aktenzeichen-xy-14530912.html

Statista. (2019). Vergewaltigungsstatistik Deutschland-Fälle bis 2018. https://de.statista.com/statisti k/daten/studie/1587/umfrage/vergewaltigung-und-sexuelle-noetigung

Steven, E. (2005). DNA-Analyse-Im Namen der Sicherheit. Gen-ethischer Informationsdienst, 170, 3-5.

U.N.E.S.C.O. (1950). The Race Question: Unesco Publication 791. In UNESCO and its programme, 3. U.N.E.S.C.O. https://unesdoc.unesco.org/ark:/48223/pf0000128291

V.I.S.A.G.E. (2019). VISible Attributes Through GEnomics. VISAGE Project \& Consortium. http://www.vi sage-h2020.eu

Vogel, G. (2018). German law allows use of DNA to predict suspects' looks. Science, 360(6391), 841-842. https://doi.org/10.1126/science.360.6391.841

Wagenmann, U. (2000). Im Fadenkreuz der Datensammler. Gen-ethischer Informationsdienst, 143, 9-12. 
Wagenmann, U., \& Schultz, S. (2017). Chronologie: DNA-Datenbanken ein historischer Rückblick. In Identität auf Vorrat: Zur Kritik der DNA-Sammelwut. Assoziation A.

Weichert, T. (2018). Forensische DNA-Analysen und der Datenschutz. Datenschutz und Datensicherheit - DuD, 42(6), 358-363. https://doi.org/10.1007/s11623-018-0956-7

Weitz, S., \& Buchanan, N. (2017). Eine Technologie der Angstkultur. freispruch, 11, 13-17.

W.I.E.-D.N.A. (2019). Statement von WIE-DNA zu Erweiterten DNA-Analysen im Gesetzesentwurf für die Modernisierung des Strafverfahrens, 08.10.2019. http://www.wie-dna.de/statement-stpo

Wienroth, M., Morling, N., \& Williams, R. (2015). Technological Innovations in Forensic Genetics: Social, Legal and Ethical Aspects. Recent Advances in DNA \& Gene Sequences (Formerly Recent Patents on DNA \& Gene Sequences), 8(2), 98-103. https://doi.org/10.2174/2352092209666150328010557

Wise, J. (2010). Providing the CSI Treatment: Criminal Justice Practitioners and the CSI Effect. Current Issues in Criminal Justice, 21(3), 383-399. https://doi.org/10.1080/10345329.2010.12035856

Published by

IIIII

Alexander von Humboldt INSTITUTE FOR INTERNET AND SOCIETY in cooperation with

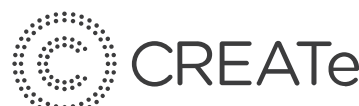

centre

cnrs - internet

et societe

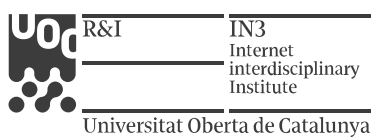

Universitat Oberta de Catalunya

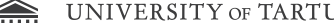

III!I Johan Skytte Institute of Political Studies 